\title{
A Brief Analysis of Corrective Feedback in Oral Interaction*
}

\author{
Ying Zhang \\ English Department, Ordnance and Engineering College, Shijiazhuang, China \\ Email: zhangying672000@yahoo.com.cn \\ Lanqin Zhang \\ English Department, Ordnance and Engineering College, Shijiazhuang, China \\ Leilei Ma \\ English Department, Ordnance and Engineering College, Shijiazhuang, China
}

\begin{abstract}
Over the last few years, the role of corrective feedback in language acquisition has become a highly controversial issue. Though disputed theories and research articles collide with each other, there appears to be a growing consensus among the majority of researchers and language practitioners concerning the significance of the role played by corrective feedback in the process of second language acquisition. Systematical theories on oral error feedback have been established over the past few decades. Many researchers, such as Bailey, Chaudron, Long, etc., have contributed much to this field. They bring forward the models and measures for oral error feedback. On the basis of the model proposed by Chaudron, this thesis deals with a comparison of students' and teachers' attitudes towards oral error feedback.
\end{abstract}

Index Terms —-second language acquisition, corrective feedback, oral interaction, attitude

\section{INTRODUCTION}

As the focus of classroom instruction has shifted over the past few decades from an emphasis on language forms to functional language within communicative context, the question of the place of error correction has become more and more important (Brown, 2004). Over the last few years, the role of corrective feedback in language acquisition has become a highly controversial issue. Though disputed theories and research articles collide with each other, there appears to be a growing consensus among the majority of researchers and language practitioners concerning the significance of the role played by corrective feedback in the process of second language acquisition. Second language acquisition researchers' opinions on the effectiveness of corrective feedback are different. One group holds that corrective feedback is necessary (e.g. White, 1991) because it can match the learners' utterance with its corresponding version in the target language and draw the learners' attention to structures that have not been mastered, thus initiating a learning process; while another group maintains that changes in the learner's competence can only be initiated by primary linguistic data, not by corrective feedback recognized as such (e.g. Schwartz, 1993) and some researchers even advocate to abandon the corrective feedback in classroom interaction due to its problems (e.g. Truscott, 1999).

A number of studies have examined whether corrective feedback in a communicative or task-based language classroom is effective. Their studies provide positive evidence for the effect of formal instruction and corrective feedback in improving the students' accuracy level on certain targeted linguistic features.

\section{LITERATURE REVIEW}

\section{A. Definition of Error Feedback}

Chaudron (1998) holds that the term corrective feedback incorporates different layers of meaning. In Chaudron's view, treatment of error may simply refer to "any teacher behavior following an error that minimally attempts to inform the learner of the fact of error".

Lightbown and Spada (1999) define corrective feedback as: any indication to the learners that their use of the target language is incorrect. This includes various responses that the learners receive. When a language learner says, "she clean the room everyday", corrective feedback can be explicit, for example, "no, you should say cleans, not clean" or implicit "yes, she cleans the room everyday", and may or may not include metalinguistic information, for example, "Don't forget to make the verb agree with the subject".

Long's (1996) view of feedback in general is more comprehensive. It suggests that environmental input can be thought of in terms of two categories that are provided to the learners about the target language: positive evidence and

\footnotetext{
* This thesis has been sponsored by the department sustentation fund (JXJJ1007).
} 
negative evidence. Long defines positive evidence as providing the learners with models of what is grammatical and acceptable in the target language; and negative evidence as providing the learners with direct or indirect information about what is unacceptable.

In this thesis, all the terms about corrective feedback refer to the same meaning: any indication to the learners that their use of the target language is incorrect.

\section{B. Theoretical Stances of the Role of Corrective Feedback}

The role of corrective feedback in the process of learning a foreign language is closely related to the conception of the role of different kinds of language input in language acquisition (Doughty \& Williams, 1998). Whether it is positive input/evidence or negative input/evidence has the greater impact.

According to nativist theory, advocated by Chomsky (1975), negative input/evidence hardly plays any role at all, which is based on Chomsky's "theory of Universal Grammar". The nativists believe what makes language acquisition is UG and instruction has little impact on forms within UG. (Carroll, 1996).

Gass argues that corrective feedback function as an attention-getting device and without direct or frequent corrective feedback in the input, which would permit learners to detect discrepancies between their learner language and the target language, fossilization may occur. Ellis (1991) shares the similar view that the acquisition process includes the steps of noticing, comparing and integrating.

Corrective feedback or negative evidence plays a crucial role in the hypothesis testing models of acquisition, in which the learner is assumed to formulate hypotheses about the target language, and to test these hypotheses against the target norm. Ohta (2001) takes corrective feedback a step further by showing that if the correct form is provided, learners may have the chance to compare their own production with that of another. In this way, corrective feedback may stimulate hypothesis testing, giving the learner the opportunity to grapple with form-meaning, relationships.

\section{DISCUSSIONS AND ANALYSIS}

The author designed a simple questionnaire mainly focusing on whether learner errors should be corrected or not, when errors should be corrected, what kinds of errors should be corrected, how errors should be corrected and who should correct learner errors. In this study, the author wants to explore whether there are any significant differences between students' and teachers' attitudes towards oral error feedback in classroom interaction.

The results reveal that students and teachers do have some different perceptions of error feedback. Though most of the students and teachers hold positive attitudes towards oral error feedback, they have different opinions on some specific questions. Most students hold that "every error in their oral production should be corrected", but the majority of teachers hold opposite opinions. Most teachers hold that too much error correction may make them frustrated and even lose confidence but students do not agree. The differences of their opinions indicate that students need more corrective feedback than teachers expected.

The findings reveal that students and teachers think phonological, lexical, grammatical errors should be corrected, but their perceptions of whether different error types should deserve the same attention are significantly different. Students hold that lexical errors should deserve the most attention; grammatical errors rand the second and phonological errors rank the last. However, teachers report that they provide the most feedback to lexical errors; phonological and grammatical errors share the second. This reveals that the mean of each error type for students is much lower than the mean for teachers, which indicate that students expect more feedback from their teacher.

Students' and teachers' attitudes towards when learner errors should be corrected are significantly different. To phonological errors, most students like immediate treatment best and dislike delayed treatment. To lexical and grammatical errors, students like delayed treatment best. However, to phonological and grammatical errors, most teachers like delayed treatment best and postponed treatment the second.

As to how to correct learner errors, there are significant differences between students and teachers. Students say they prefer explicit correction and only a few like metalinguistic clues better. But teachers provide different feedback types across different error types: to phonological errors, teachers like to use explicit correction and metalinguistic clues; to lexical errors, teachers like to use explicit correction; to grammatical errors, metalinguistic clues are preferred. Even to the same type of error, different teachers may employ different types of error feedback.

The findings do not suggest significant differences between students' and teachers' attitudes towards who should correct learner errors. Most students and teachers hold that to phonological, lexical and grammatical errors, teacher-correction is better than self-correction or peer correction.

\section{PedagogicAl IMPlicAtions}

Oral error feedback is a complex decision making process. When a student commits an error, the teacher firstly should decide which kind of error it is, whether to correct it, if so when and how to correct it, and who should correct it. Teachers should take students' cognitive, affective reality and as well as students' preferences of error feedback into consideration. 
Providing effective oral error feedback is a difficult and complex process involving many challenges and complexities, and probably the most difficult aspect of the correction process is tailoring corrections to individual students. Teachers who wish to give effective feedback should consider its effects on each individual student. They should know their students well, including their language proficiency, characters, preferences, etc, and also should know when and how to correct their errors.

Only by bearing students' cognitive, affective reality and preferences of feedback in mind, can teachers provide effective feedback and otherwise, the feedback will be unfruitful.

\section{REFERENCES}

[1] Brown, H. D. (2004). Principles of Language Learning and Teaching. Foreign Language Teaching and Research Press.

[2] Chaudron, C. (1988). Second Language Classrooms: Research on Teaching and Learning. Cambridge, UK: Cambridge University Press.

[3] Carroll, S. (1996). The Irrelevance of Verbal Feedback to Language Learning. In L, Eubank, The current State of Interlanguage. Amsterdam: John Benjamins.

[4] Doughty, C., \& Williams, J. (1998). Pedagogical Choices in Focus on Form. In C. Doughty \& Williams, Focus on Form in Classroom Second Language Acquisition. New York: Cambridge University Press.

[5] Elllis, R. (1991). Grammar Teaching Practice or Consciousness-raising? In R.Ellis, Second Language Acquisition and Second Language Pedagogy.

[6] Lightbown, P. M. \& N. Spada (1999). How Languages are Learned. Oxford, UK: Oxford University Press.

[7] Ohta, A. S. (2001). Second Language Acquisition Processes in the Classroom: Learning Japanese. Mahwah, NJ: Lawrence Erlbaum.

[8] Schwartz, B. (1993). On Explicit and Negative Data Effective and Affecting Competence and Linguistic Behavior. Studies in Second Language Acquisition.

[9] Truscott, John. (1999). What's Wrong with Oral Grammar Correction, The Canadian Modern Language Review.

[10] White, L (1991). Adverb Placement in Second Language Acquisition: Some Effects of Positive and Negative Evidence in the Classroom. Second Language Research.

Ying Zhang was born in Hebei, China in 1978. She received her M.A. degree in linguistics from Beijing Languages and Culture University, China in 2008.

She is currently a lecturer in English Department of Ordnance and Engineering College, Shijiazhuang, China. Her research interests include teaching methodology and applied linguistics.

Lanqin Zhang was born in Hebei, China in 1954. She received her B.A. degree from PLA Foreign Languages University, China. She is currently a professor in English Department of Ordnance and Engineering College, Shijiazhuang, China. Her research interests include translation and social linguistics.

Leilei Ma was born in Hebei, China in 1971. She received her M.A. degree in English literature from Hebei University in 1997. She is currently a lecturer in English Department of Ordnance and Engineering College, Shijiazhuang, China. Her research interests include English literature and teaching methodology. 